\title{
Mineralocorticoid Receptor Blocker Protects against Podocyte-Dependent Glomerulosclerosis
}

\author{
Nobuaki Takagi ${ }^{\text {Takakuni Tanizawa }}{ }^{\mathrm{c}}$ Valentina Kon ${ }^{\mathrm{a}}$ \\ Agnes B. Fogo ${ }^{a}$ b lekuni Ichikawa ${ }^{a} \quad$ Ji Ma $^{a}$ \\ ${ }^{a}$ Division of Nephrology, Department of Pediatrics, and ${ }^{\mathrm{b}}$ Department of Pathology, Vanderbilt \\ University, Nashville, Tenn., USA; 'D Department of Pediatrics, Hyogo College of Medicine, \\ Nishinomiya, Japan
}

\section{Key Words}

Podocyte $\cdot$ Glomerulosclerosis $\cdot$ Proteinuria $\cdot$ Angiotensin II $\cdot$ Aldosterone $\cdot$ Receptor $\cdot$ NEP25 . Blood pressure

\begin{abstract}
Background: We previously showed that angiotensin type 1 receptor (AT1) blocker (ARB) attenuates glomerular injury in Nphs1-hCD25 (NEP25) transgenic mice, a model of selective podocyte injury. However, subsequent studies in NEP25 mice with podocyte-specific deficiency of AT1 revealed that the protective effects of ARB are not through the podocyte AT1, thereby raising the possibility that the protective effects of ARB involve mineralocorticoids. Methods: NEP25 mice were treated with the mineralocorticoid receptor blocker (MRB) spironolactone (25 $\mathrm{mg} / \mathrm{kg} / \mathrm{day}, \mathrm{n}=10)$, the ARB losartan $(250 \mathrm{mg} / \mathrm{kg} /$ day, $\mathrm{n}=11)$, both (ARB+MRB, $\mathrm{n}=8$ ) or vehicle (Vehicle, $n=9$ ) from day -7 to day 9 of induction of podocyte injury. Results: Although MRB did not reduce systolic blood pressure or proteinuria, addition of MRB to ARB significantly attenuated glomerulosclerosis (glomerulosclerosis index: ARB+MRB $1.67 \pm 0.19$ vs. MRB $2.01 \pm 0.29$, ARB $2.35 \pm 0.19$, and Vehicle $2.25 \pm 0.26, \mathrm{p}<0.05$ ) and preserved the number of WT1-positive podocytes (ARB+MRB $152.5 \pm 9.7$ vs. MRB $117.2 \pm 9.0$ or ARB $113.6 \pm 7.4$, and ARB+MRB vs. Vehicle $97.5 \pm 4.0$ per glomerulus; $p<0.05$ ). Conclusion: These data suggest that, while MRB does not attenuate proteinuria caused by podocyte-specific injury, it provides protective effects against glomerulosclerosis that is independent of systemic blood pressure.
\end{abstract}




\section{Introduction}

Podocytes are visceral epithelial cells that form the outer layer of the glomerular filtration barrier, and serve as an important defense against urinary protein loss in the normal glomerulus [1]. Dysfunction and loss of podocytes have been regarded as playing a critical role in the development of glomerulosclerosis [2]. Our previous studies with a podocytespecific injury model, Nphs1-hCD25 (NEP25) transgenic mouse [3], together with others [4-6] have shown that podocyte-specific injury causes proteinuria and glomerulosclerosis. Models of podocyte damage-induced glomerulosclerosis have also shown that blockade of the angiotensin type 1 receptor (AT1) attenuates podocyte damage and glomerulosclerosis $[3,7,8]$. Importantly, however, our most recent study with the NEP2 5 mice has revealed that this protective effect of the AT1 antagonist is not through podocyte-specific AT1 [8], raising the possibility of AT1-independent mechanisms.

Aldosterone is a major mineralocorticoid, the synthesis of which occurs primarily in the adrenal gland and is stimulated primarily by angiotensin II via AT1 $[9,10]$. Expression of mineralocorticoid receptor has been found in podocytes in vivo [11]. Several in vitro studies have suggested that aldosterone can directly injure podocytes through mineralocorticoid receptor [12-14]. In animal models with glomerular injury, treatment with mineralocorticoid receptor blocker (MRB) protects against podocyte injury and glomerulosclerosis [1517]. In humans, MRB decreased the amount of proteinuria in patients with chronic renal injuries [9, 18-20]. In rat models with hypertension [21, 22], diabetes [23], renal mass reduction [24, 25], radiation injury [16] and adriamycin-induced nephrosis [26], addition of MRB to $\mathrm{ARB}$ or angiotensin-converting enzyme inhibitor (ACEI) lessened podocyte damage. The current study examines the role of mineralocorticoid receptor in podocyte injury and podocyte injury-induced glomerulosclerosis as well as its relationship to AT1 blockade in NEP25 mice.

\section{Animals and Methods}

\section{Animals}

All animal procedures used in the study were approved by the Institutional Animal Care and Use Committee (IACUC) at Vanderbilt University. Male and female NEP25 mice with $\mathrm{C} 57 \mathrm{BL} / 6 \mathrm{~J}$ genetic background were housed under normal conditions with $20^{\circ} \mathrm{C}, 12$ hour light/dark cycle. Mice had free access to normal rodent chow and water. At 12-18 weeks of age, mice were randomly allocated to one of the following 4 groups; control drinking water containing $2 \%$ ethanol (Vehicle, $\mathrm{n}=9$ ), spironolactone water $(\mathrm{MRB}, 100 \mathrm{mg} / \mathrm{l}$, $\mathrm{n}=10$ ), losartan (ARB, $1 \mathrm{~g} / \mathrm{l}, \mathrm{n}=11$ ), or a combination of spironolactone and losartan ( $\mathrm{ARB}+\mathrm{MRB}, \mathrm{n}=8)$. Measured drug consumption was $250 \mathrm{mg} / \mathrm{kg} /$ day for losartan and 25 $\mathrm{mg} / \mathrm{kg} /$ day for spironolactone throughout the study period [25]. In order to induce uniform podocyte damage, a large dose of anti-human CD25 recombinant immunotoxin (LMB2, 20 ng/g body weight) diluted with phosphate-buffered saline was injected intraperitoneally. LMB2 did not cause any systemic and renal injury in wild-type mice [3]. Preliminary experiments showed that this LMB2 dosage caused nephrosis evidenced by systemic edema and established glomerulosclerosis within 2 weeks and death within 4 weeks. Drugs were started at 7 days before (day -7) LMB2, and mice were sacrificed on day 9, at a time when body weight increase and proteinuria plateaued, edema became obvious, and glomerulosclerosis manifested. 


\section{Blood Pressure Measurement}

Conscious mice were prewarmed at $37^{\circ} \mathrm{C}$ for $10 \mathrm{~min}$ before measurement. Systolic blood pressure (SBP) was measured using tail-cuff plethysmography (BP-2000 Blood Pressure Analysis System; Visitech Systems, Apex, N.C., USA). Final SBP readings were obtained by averaging $6-10$ successful readings.

\section{Urine and Blood Biochemical Analysis}

Spot urine was collected. Concentration of total protein was measured by the BCA method, and creatinine was measured by the picric acid method (Exocell, Philadelphia, Pa., USA). Concentration of albumin in the urine was determined by ELISA (Albuwell M; Exocell). Urinary and serum sodium and potassium were measured by flame spectrophotometry.

\section{Morphological and Immunohistochemical Analysis}

Kidneys were fixed in $4 \%$ buffered paraformaldehyde overnight at $4^{\circ} \mathrm{C}$, processed and embedded in paraffin, and cut in $2-\mu \mathrm{m}$ sections, which were stained with PAS. Each glomerulus was graded on a $0-4$ scale, which represents the sclerotic area involving $0,1-25$, $26-50,51-75$, or $>75 \%$ of the glomerulus. Scores for all of the glomeruli on a section were averaged and defined as the sclerosis index for each mouse [3].

Glomerular deposition of collagen IV, podocyte marker Wilms' tumor suppressor gene 1 (WT1), and serum/glucocorticoid-regulated kinase 1 (SGK1) were detected by immunohistochemistry. Briefly, after quenching endogenous peroxidase with $1 \% \mathrm{H}_{2} \mathrm{O}_{2}$ in methanol, tissue sections were treated with $0.2 \mathrm{mg} / \mathrm{ml}$ trypsin $/ \mathrm{PBS}$ at $37^{\circ} \mathrm{C}$ for collagen IV staining, or with microwave heat in citrate buffer for WT1 and SGK1 staining. Sections were then incubated with rabbit anti-mouse collagen IV (Serotec, Oxford, UK) at 1:1,000 dilution, rabbit anti-mouse WT1 (Santa Cruz Biotechnology, Santa Cruz, Calif., USA) at 1:800, or rabbit anti-SGK1 (Abcam Inc., Cambridge, Mass., USA) at 1:2,000 dilution overnight at $4^{\circ} \mathrm{C}$. Standard blocking, secondary antibody incubation and developing procedures were applied according to the instructions provided by the corresponding MOM or ABC kit (Vector Laboratories, Burlingame, Calif., USA). Immunostainings were visualized by diaminobenzidine, and the digital images were captured at $\times 40$ magnification. Podocytes stained for WT1 were quantitated by ImageJ software. Briefly, the color of positive staining was extracted by the plugin Colour Deconvolution function. The threshold of maximum color entry was determined by the investigator so that only dark-brown positive signals were entered for analysis, and assigned under the plugin Filter function. The number and size of WT1-positive podocytes in an outlined glomerulus as well as the glomerular area were then measured. The podocyte density in the glomerular sphere and the glomerular volume were computed according to the Weibel-Gomez equation based on stereological principles [27,28], and the average number of podocyte per glomerulus was calculated from $>30$ measured glomeruli for each kidney section. The collagen IV-positive area fraction in the glomerulus was also quantified by ImageJ. Data from all glomeruli were then averaged for each animal. All morphometric analyses were done by trained laboratory staff blinded to group allocation.

\section{Statistical Analysis}

Results are expressed as means \pm SE. Analysis of variance (ANOVA) and post-hoc Tukey test were used to evaluate differences between the groups. Nonparametric MannWhitney $U$ test was used for between-group comparisons when data were not normally distributed. All tests were two-tailed, and $\mathrm{p}<0.05$ was considered statistically significant. 
Table 1. Body weight, SBP and proteinuria

\begin{tabular}{|c|c|c|c|c|c|c|}
\hline & \multirow[t]{2}{*}{ Group } & \multicolumn{5}{|c|}{ Time from induction of podocyte damage } \\
\hline & & day -7 & day -4 & day 0 & day 4 & day 8 \\
\hline \multirow{4}{*}{$\begin{array}{l}\text { Body weight, } \\
\% \text { change } \\
\text { from day }-7\end{array}$} & Vehicle & & $-1.75 \pm 0.46$ & $0.71 \pm 0.39$ & $4.10 \pm 1.72$ & $21.11 \pm 4.55$ \\
\hline & $\mathrm{ARB}$ & & $-6.41 \pm 2.37$ & $-4.40 \pm 2.49$ & $-0.78 \pm 3.01$ & $11.55 \pm 3.44$ \\
\hline & MRB & & $0.39 \pm 0.49$ & $0.44 \pm 0.60 \dagger$ & $4.53 \pm 1.83$ & $21.89 \pm 4.84$ \\
\hline & $\mathrm{ARB}+\mathrm{MRB}$ & & $-4.15 \pm 2.47$ & $-2.55 \pm 1.37$ & $-0.58 \pm 1.33$ & $4.86 \pm 2.18^{* \text { ま }}$ \\
\hline \multirow{4}{*}{$\begin{array}{l}\text { Systolic blood } \\
\text { pressure, } \\
\text { mm Hg }\end{array}$} & Vehicle & $105.29 \pm 2.26$ & $110.73 \pm 3.20$ & $118.47 \pm 2.61$ & $112.40 \pm 5.78$ & $95.21 \pm 7.00$ \\
\hline & ARB & $106.79 \pm 3.72$ & $95.80 \pm 2.96^{*}$ & $91.09 \pm 3.18^{*}$ & $92.10 \pm 6.82^{*}$ & $81.76 \pm 2.63$ \\
\hline & $\mathrm{MRB}$ & $109.38 \pm 1.29$ & $109.24 \pm 2.81^{\dagger}$ & $112.58 \pm 4.19^{\dagger}$ & $114.73 \pm 4.70^{\dagger}$ & $103.95 \pm 6.73$ \\
\hline & $\mathrm{ARB}+\mathrm{MRB}$ & $101.80 \pm 3.78$ & $86.33 \pm 3.87^{* \text {, }}$ & $84.82 \pm 2.90^{* \text {, }}$ & $84.35 \pm 3.95^{* \ddagger}$ & $86.68 \pm 5.26^{\ddagger}$ \\
\hline \multirow{4}{*}{$\begin{array}{l}\text { Urine albumin- } \\
\text { to-creatinine } \\
\text { ratio, } \mu \mathrm{g} / \mathrm{mg}\end{array}$} & Vehicle & $30.21 \pm 13.77$ & & $13.19 \pm 8.12$ & $299.68 \pm 95.7$ & $491.31 \pm 89.20$ \\
\hline & ARB & $14.10 \pm 4.37$ & & $6.23 \pm 1.05$ & $81.49 \pm 17.15^{*}$ & $369.03 \pm 62.55$ \\
\hline & $\mathrm{MRB}$ & $12.26 \pm 2.09$ & & $4.85 \pm 0.74$ & $203.75 \pm 53.52$ & $466.05 \pm 54.82$ \\
\hline & $\mathrm{ARB}+\mathrm{MRB}$ & $26.47 \pm 13.51$ & & $9.47 \pm 3.53$ & $49.16 \pm 19.01^{*}$ & $260.74 \pm 48.76^{*}$ \\
\hline
\end{tabular}

Figures are means $\pm \mathrm{SE} .{ }^{*} \mathrm{p}<0.05$ vs. Vehicle, ${ }^{\dagger} \mathrm{p}<0.05$ vs. ARB, ${ }^{\ddagger} \mathrm{p}<0.05$ vs. MRB.

\section{Results}

Systemic Parameters and Drug Effect

Systemic edema was evident in all mice after induction of podocyte damage by LMB2 injection. Vehicle control mice had 20\% increase in body weight by day 8 (table 1). Treatment with MRB or ARB alone did not prevent the increase in body weight, while ARB+MRB treatment significantly attenuated edema and increased body weight.

To follow the effects of spironolactone, urinary $\mathrm{Na}^{+} / \mathrm{K}^{+}$ratio was measured 4 days after initiation of spironolactone treatment. Serum $\mathrm{K}^{+}$measured at sacrifice on day 9 was $5.86 \pm$ $0.08 \mathrm{mmol} / \mathrm{l}$ in Vehicle, $5.41 \pm 0.21 \mathrm{in} \mathrm{ARB}, 5.69 \pm 0.32$ in $\mathrm{MRB}$, and $6.46 \pm 0.21 \mathrm{in}$ $\mathrm{ARB}+\mathrm{MRB}$ (ARB vs. ARB+MRB, $\mathrm{p}<0.05$ ). $\mathrm{MRB}$ tended to increase the $\mathrm{Na}^{+} / \mathrm{K}^{+}$ratio compared to control (MRB $0.975 \pm 0.225$ vs. Vehicle $0.872 \pm 0.073, \mathrm{p}=0.10$ ).

The SBP did not differ at baseline (day -7 ) among the 4 groups. ARB significantly decreased SBP throughout duration of the study. MRB alone did not affect the SBP over the course of the study, and addition of MRB to ARB did not further decrease the SBP. Vehicle mice had slightly lowered SBP on day 8 that coincided with increased body weight and albuminuria, consistent with their nephrotic status (table 1).

SGK1 stained positively in the kidneys from the Vehicle group, mainly in the tubules, while there was only a little expression in the ARB, MRB and ARB+MRB groups, suggesting the blockade of mineralocorticoid receptor and AT1 (fig. 1).

\section{Proteinuria}

Vehicle control mice developed massive albuminuria following induction of podocyte damage (table 1). ARB treatment significantly decreased the amount of albuminuria on day 4, while MRB treatment did not lessen the albuminuria. Addition of MRB to ARB caused a significant decrease of proteinuria on day 4 and day 8 .

\section{Glomerulosclerosis}

Glomerulosclerosis was evident in all mice after induction of podocyte damage. ARB or MRB alone significantly lessened sclerosis evidenced by decreased glomerular deposition of 
Table 2. Glomerular histology

\begin{tabular}{lrlll}
\hline Group & $\mathrm{n}$ & GSI & Collagen type IV, \% & WT1+ cells, /glomerulus \\
\hline Vehicle & 9 & $2.249 \pm 0.261$ & $38.87 \pm 1.17$ & $97.5 \pm 4.0$ \\
ARB & 10 & $2.350 \pm 0.187$ & $33.11 \pm 1.57^{*}$ & $113.6 \pm 7.4$ \\
MRB & 10 & $2.009 \pm 0.294$ & $29.87 \pm 1.68^{*}$ & $117.2 \pm 9.0$ \\
ARB+MRB & 8 & $1.668 \pm 0.187^{*, \dagger}$ & $23.72 \pm 1.44^{*, \dagger, \ddagger}$ & $152.5 \pm 9.7^{*, \dagger, \ddagger}$ \\
\hline
\end{tabular}

Figures are means $\pm \mathrm{SE} .{ }^{*} \mathrm{p}<0.05$ vs. Vehicle, ${ }^{\dagger} \mathrm{p}<0.05$ vs. ARB, ${ }^{\ddagger} \mathrm{p}<0.05$ vs. MRB.
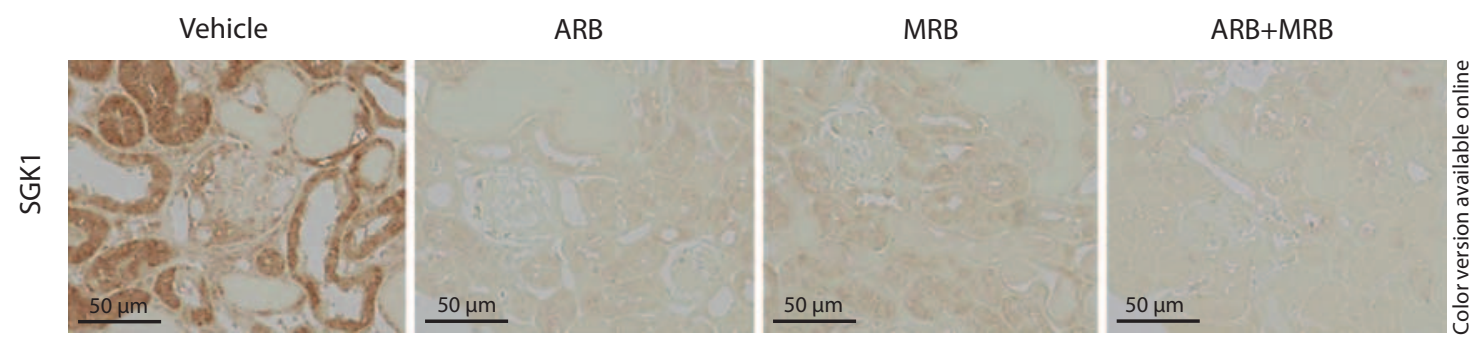

Fig. 1. SGK1 staining in NEP25 mice treated with ARB, MRB or both. NEP25 mice from the Vehicle group showed SGK1-positive staining in both tubular epithelial cells and glomeruli, while there were only a few positivities in the ARB, MRB and ARB+MRB groups, suggesting the effects of ARB and/or MRB.

collagen IV, although the glomerulosclerosis index (GSI) did not change. Combination of $\mathrm{ARB}$ and MRB significantly decreased the glomerular collagen IV-positive area as well as GSI. The collagen IV-positive area in the glomeruli of ARB+MRB mice was further decreased compared with glomeruli of mice with ARB or MRB treatment alone (fig. 2 and table 2).

\section{Podocyte Injury}

Expression of WT1, a podocyte differentiation marker, was significantly downregulated in Vehicle-treated NEP25 mice with podocyte damage. ARB and MRB alone tended to preserve the number of WT1-positive podocytes (ARB vs. Vehicle, $\mathrm{p}=0.053$; MRB vs. Vehicle, $\mathrm{p}=0.072$ ). Mice treated with combined $A R B+M R B$ had a significantly greater number of podocytes compared with the Vehicle, ARB, or MRB (fig. 2 and table 2).

\section{Discussion}

Both ARB $[8,29]$ and MRB $[14,17,30]$ have been shown to have a protective effect against chronic glomerular diseases, and protect podocytes from injury. Our current study showed that in NEP25 mice, a model of podocyte-targeted glomerular injury and sclerosis, treatment with the ARB losartan significantly alleviated massive proteinuria and podocyte loss, along with decreased blood pressure and less glomerular collagen IV deposition. Treatment with the MRB spironolactone protected against glomerulosclerosis and podocyte loss without affecting proteinuria or blood pressure. Further, although addition of MRB to ARB did not provide additional benefits in blood pressure or proteinuria reduction, there was significant attenuation in glomerulosclerosis compared with ARB treatment alone. 

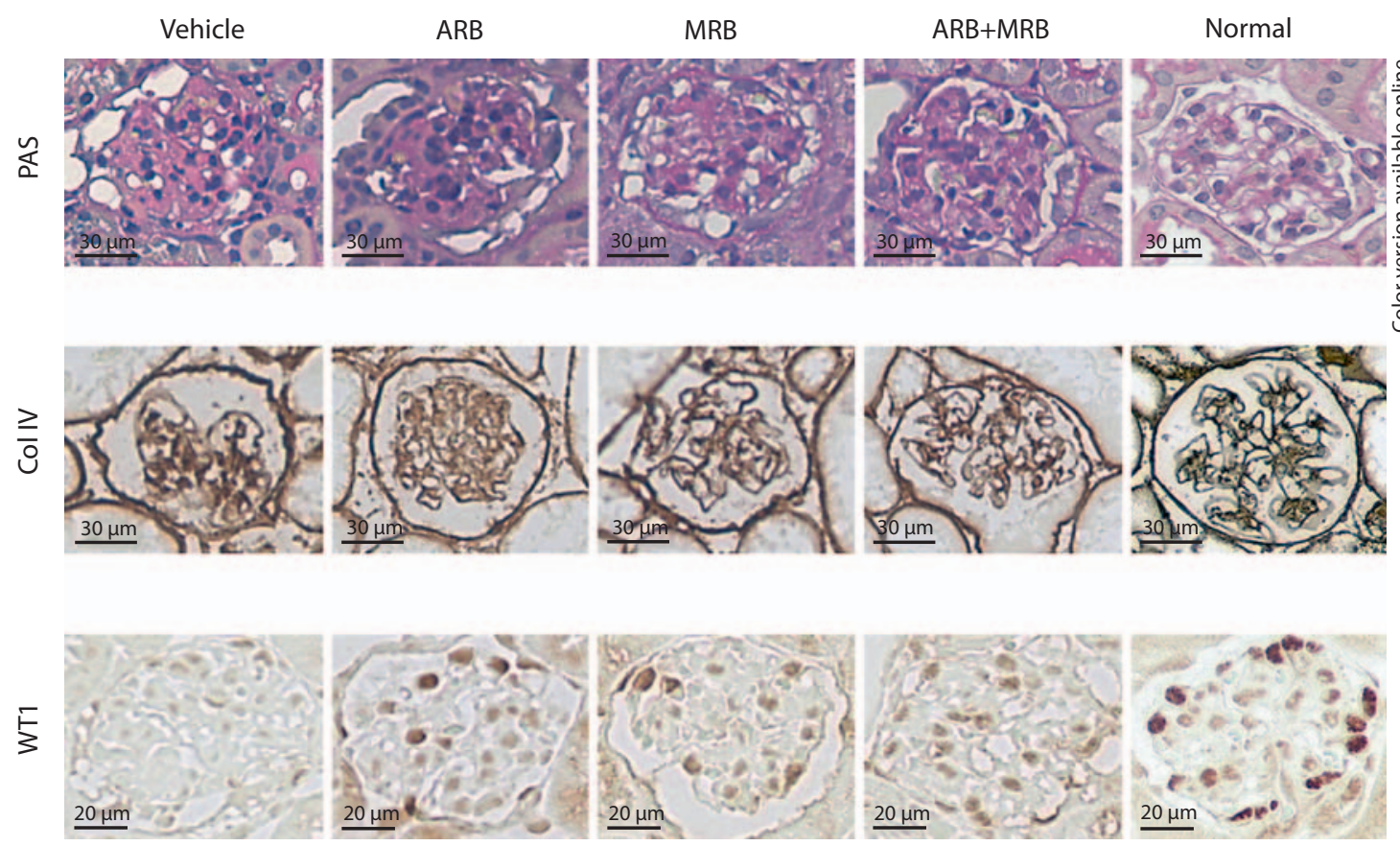

Fig. 2. Histology of NEP 25 mice treated with ARB, MRB or both. NEP 25 mouse, a model of specific podocyte damage, showed extensive glomerulosclerosis, an increased area positive for collagen IV (Col IV) and a decreased number of WT1-positive podocytes in the glomerulus. Treatment with the ARB losartan, the MRB spironolactone, or with both in combination attenuated podocyte damage-induced glomerulosclerosis, collagen deposition and podocyte loss.

The current study in NEP25 transgenic mice with targeted podocyte damage showed that large doses of ARB significantly reduced proteinuria, suggesting a protection of podocytes. This significant reduction in proteinuria was accompanied by significantly decreased blood pressure. These results, together with our previous observations that podocyte-specific inactivation of the AT1 gene did not protect against podocyte damage and glomerulosclerosis in the NEP25 model [8], indicate that the protective effects of ARB against podocyte injury is not through its direct effect on podocyte AT1. Instead, the results are consistent with the notion that the salutary effect occurs through decreasing glomerular pressure or other effects on the glomerular filtration barrier [31,32]. Of note, although considerable evidence shows that blocking the angiotensin system by ARB or ACEI reduces proteinuria and attenuates the progression of renal failure in patients and animals with chronic glomerular lesions, these interventions have only limited effectiveness in established late stages of glomerulosclerosis $[33,34]$. In animal models with podocyte-specific injury, the degree of proteinuria at the early stages parallels severity of podocyte injury $[3,6]$. Thus, the current results complement these findings with the observation of only limited protective effects of these interventions in the rapidly progressive advanced glomerulosclerosis occurring in NEP25 mice.

Activation of the mineralocorticoid receptor occurs in kidneys with proteinuria and podocyte injury $[14,19,35,36]$, and MRB attenuates the proteinuria and podocyte injury, as well as glomerulosclerosis and renal fibrosis in several pathophysiological conditions $[15,17$, $25,37-39]$. While proteinuria is an important prognostic index in chronic glomerular diseases $[40,41]$, its correlation with glomerular morphological findings is lost at the later stag- 
es [42]. Therefore, the lack of effect of MRB on proteinuria found in our NEP25 model is not surprising; it does suggest, however, that the protective effect of MRB is not through direct podocyte protection, either. This lack of effect on proteinuria paralleled a lack of effect on blood pressure.

Although the cellular mechanisms of beneficial effects of MRB against glomerular injury are not fully elucidated, involvement of a few profibrotic factors has been suggested [15, $16,39,43,44]$ along with systemic and/or glomerular hypertension [45]. In our study, MRB provided significant protection against glomerulosclerosis despite the lack of reduction in proteinuria and blood pressure. Blood pressure- and proteinuria-independent effects on glomerular injury have also been reported in subtotally nephrectomized rats [15, 25]. In this connection, even though aldosterone is largely under the influence of angiotensin II [9], additional angiotensin II-independent protective effects of MRB against glomerular injury have been reported $[15,16,23,46]$. The additive effect of MRB on attenuation of glomerulosclerosis demonstrated in animals given a large dose of ARB in our study but not in a subtotal nephrectomy model [25] indicates that the prosclerotic effect of mineralocorticoid receptor activation in the podocyte-specific damage-triggered glomerular deterioration is AT1 independent.

In the later stages of glomerulosclerosis, such as one studied in the present study, the observed injury of podocyte is the combined consequence of propagation of podocyte damage [47] and other glomerular pathophysiological changes, such as protein leakage through glomerular filtration barrier as well as loss of glomerular population. It is conceivable, then, that the preservation of WT1-positive podocytes by MRB treatment found in our study is, to a large extent, attributed to its effects to prevent glomerulosclerosis and loss, while the protection of ARB treatment reflects its early antiproteinuric effect.

In summary, using a transgenic mouse model of severe glomerulosclerosis induced by specific podocyte damage, we found that blockade of mineralocorticoid receptor by spironolactone significantly attenuated glomerulosclerosis, independent of its effects on proteinuria and blood pressure. The current results in a model with podocyte-specific damage-induced rapidly progressing glomerulosclerosis, together with our previous studies, suggest that the glomerular protective effects of angiotensin-aldosterone blockade are not dependent on direct podocyte protection.

\section{Acknowledgments}

The authors thank Drs. Hai-Chun Yang and Chuan-Ming Hao for valuable assistance for the project. This work was supported by fundings from the National Institute of Diabetes and Digestive and Kidney Diseases (DK037868 and DK044757).

\section{Disclosure Statement}

The authors have no conflicts of interest to declare. 


\section{References}

1 Pavenstadt H, Kriz W, Kretzler M: Cell biology of the glomerular podocyte. Physiol Rev 2003;83: 253-307.

-2 D'Agati VD: Podocyte injury in focal segmental glomerulosclerosis: Lessons from animal models (a play in five acts). Kidney Int 2008;73:399-406.

-3 Matsusaka T, Xin J, Niwa S, Kobayashi K, Akatsuka A, Hashizume H, Wang QC, Pastan I, Fogo AB, Ichikawa I: Genetic engineering of glomerular sclerosis in the mouse via control of onset and severity of podocyte-specific injury. J Am Soc Nephrol 2005;16:1013-1023.

-4 Assmann KJ, van Son JP, Dijkman HB, Mentzel S, Wetzels JF: Antibody-induced albuminuria and accelerated focal glomerulosclerosis in the Thy-1.1 transgenic mouse. Kidney Int 2002;62:116-126.

-5 Macary G, Rossert J, Bruneval P, Mandet C, Belair MF, Houillier P, Van Huyen JP: Transgenic mice expressing nitroreductase gene under the control of the podocin promoter: a new murine model of inductible glomerular injury. Virchows Arch 2010;456:325-337.

-6 Wharram BL, Goyal M, Wiggins JE, Sanden SK, Hussain S, Filipiak WE, Saunders TL, Dysko RC, Kohno K, Holzman LB, Wiggins RC: Podocyte depletion causes glomerulosclerosis: diphtheria toxin-induced podocyte depletion in rats expressing human diphtheria toxin receptor transgene. J Am Soc Nephrol 2005;16:2941-2952.

-7 Hiramatsu N, Hiromura K, Shigehara T, Kuroiwa T, Ideura H, Sakurai N, Takeuchi S, Tomioka M, Ikeuchi H, Kaneko Y, Ueki K, Kopp JB, Nojima Y: Angiotensin II type 1 receptor blockade inhibits the development and progression of HIV-associated nephropathy in a mouse model. J Am Soc Nephrol 2007;18:515-527.

-8 Matsusaka T, Asano T, Niimura F, Kinomura M, Shimizu A, Shintani A, Pastan I, Fogo AB, Ichikawa I: Angiotensin receptor blocker protection against podocyte-induced sclerosis is podocyte angiotensin II type 1 receptor-independent. Hypertension 2010;55:967-973.

-9 Slagman MC, Navis G, Laverman GD: Dual blockade of the renin-angiotensin-aldosterone system in cardiac and renal disease. Curr Opin Nephrol Hypertens 2010;19:140-152.

-10 Foster RH: Reciprocal influences between the signalling pathways regulating proliferation and steroidogenesis in adrenal glomerulosa cells. J Mol Endocrinol 2004;32:893-902.

-11 Nagase M, Yoshida S, Shibata S, Nagase T, Gotoda T, Ando K, Fujita T: Enhanced aldosterone signaling in the early nephropathy of rats with metabolic syndrome: possible contribution of fat-derived factors. J Am Soc Nephrol 2006;17:3438-3446.

-12 Chen C, Liang W, Jia J, van Goor H, Singhal PC, Ding G: Aldosterone induces apoptosis in rat podocytes: role of PI3-K/Akt and p38MAPK signaling pathways. Nephron Exp Nephrol 2009;113:e26e34.

-13 Kiyomoto H, Rafiq K, Mostofa M, Nishiyama A: Possible underlying mechanisms responsible for aldosterone and mineralocorticoid receptor-dependent renal injury. J Pharmacol Sci 2008;108:399_ 405.

-14 Lee SH, Yoo TH, Nam BY, Kim DK, Li JJ, Jung DS, Kwak SJ, Ryu DR, Han SH, Lee JE, Moon SJ, Han DS, Kang SW: Activation of local aldosterone system within podocytes is involved in apoptosis under diabetic conditions. Am J Physiol Renal Physiol 2009;297:F1381-F1390.

-15 Aldigier JC, Kanjanbuch T, Ma LJ, Brown NJ, Fogo AB: Regression of existing glomerulosclerosis by inhibition of aldosterone. J Am Soc Nephrol 2005;16:3306-3314.

-16 Brown NJ, Nakamura S, Ma L, Nakamura I, Donnert E, Freeman M, Vaughan DE, Fogo AB: Aldosterone modulates plasminogen activator inhibitor-1 and glomerulosclerosis in vivo. Kidney Int 2000;58:1219-1227.

- 17 Nagase M, Shibata S, Yoshida S, Nagase T, Gotoda T, Fujita T: Podocyte injury underlies the glomerulopathy of Dahl salt-hypertensive rats and is reversed by aldosterone blocker. Hypertension 2006; 47:1084-1093.

-18 Bomback AS, Kshirsagar AV, Amamoo MA, Klemmer PJ: Change in proteinuria after adding aldosterone blockers to ACE inhibitors or angiotensin receptor blockers in CKD: a systematic review. Am J Kidney Dis 2008;51:199-211.

-19 Jain G, Campbell RC, Warnock DG: Mineralocorticoid receptor blockers and chronic kidney disease. Clin J Am Soc Nephrol 2009;4:1685-1691.

20 Toto RD: Aldosterone blockade in chronic kidney disease: can it improve outcome? Curr Opin Nephrol Hypertens 2010;19:444-449. 
-21 Onozato ML, Tojo A, Kobayashi N, Goto A, Matsuoka H, Fujita T: Dual blockade of aldosterone and angiotensin II additively suppresses TGF-beta and NADPH oxidase in the hypertensive kidney. Nephrol Dial Transplant 2007;22:1314-1322.

-22 Zhou X, Ono H, Ono Y, Frohlich ED: Aldosterone antagonism ameliorates proteinuria and nephrosclerosis independent of glomerular dynamics in L-NAME/SHR model. Am J Nephrol 2004;24:242-249.

-23 Kang YS, Ko GJ, Lee MH, Song HK, Han SY, Han KH, Kim HK, Han JY, Cha DR: Effect of eplerenone, enalapril and their combination treatment on diabetic nephropathy in type II diabetic rats. Nephrol Dial Transplant 2009;24:73-84.

- 24 Nemeth Z, Kokeny G, Godo M, Mozes M, Rosivall L, Gross ML, Ritz E, Hamar P: Increased renoprotection with ACE inhibitor plus aldosterone antagonist as compared to monotherapies - the effect on podocytes. Nephrol Dial Transplant 2009;24:3640-3651.

-25 Piecha G, Koleganova N, Gross ML, Geldyyev A, Adamczak M, Ritz E: Regression of glomerulosclerosis in subtotally nephrectomized rats: effects of monotherapy with losartan, spironolactone, and their combination. Am J Physiol Renal Physiol 2008;295:F137-F144.

- 26 Kramer AB, van der Meulen EF, Hamming I, van Goor H, Navis G: Effect of combining ACE inhibition with aldosterone blockade on proteinuria and renal damage in experimental nephrosis. Kidney Int 2007;71:417-424.

-27 White KE, Bilous RW: Estimation of podocyte number: a comparison of methods. Kidney Int 2004; 66:663-667.

-28 Adamczak M, Gross ML, Amann K, Ritz E: Reversal of glomerular lesions involves coordinated restructuring of glomerular microvasculature. J Am Soc Nephrol 2004;15:3063-3072.

-29 Liebau MC, Lang D, Bohm J, Endlich N, Bek MJ, Witherden I, Mathieson PW, Saleem MA, Pavenstadt H, Fischer KG: Functional expression of the renin-angiotensin system in human podocytes. Am J Physiol Renal Physiol 2006;290:F710-F719.

-30 Nagase M, Matsui H, Shibata S, Gotoda T, Fujita T: Salt-induced nephropathy in obese spontaneously hypertensive rats via paradoxical activation of the mineralocorticoid receptor: role of oxidative stress. Hypertension 2007;50:877-883.

- 31 Palatini P, Mormino P, Dorigatti F, Santonastaso M, Mos L, De Toni R, Winnicki M, Dal Follo M, Biasion T, Garavelli G, Pessina AC: Glomerular hyperfiltration predicts the development of microalbuminuria in stage 1 hypertension: the HARVEST. Kidney Int 2006;70:578-584.

- 32 Whaley-Connell A, Nistala R, Habibi J, Hayden MR, Schneider RI, Johnson MS, Tilmon R, Rehmer N, Ferrario CM, Sowers JR: Comparative effect of direct renin inhibition and AT1R blockade on glomerular filtration barrier injury in the transgenic Ren2 rat. Am J Physiol Renal Physiol 2010; 298:F655-F661.

-33 Ikoma M, Kawamura T, Kakinuma Y, Fogo A, Ichikawa I: Cause of variable therapeutic efficiency of angiotensin converting enzyme inhibitor on glomerular lesions. Kidney Int 1991;40:195-202.

- 34 Okada K, Okawa E, Shibahara H, Maruyama T, Maruyama N, Matsumoto K, Takahashi S: Combination therapy with angiotensin-converting enzyme inhibitor and oral adsorbent of uremic toxins can delay the appearance of glomerular sclerosis and interstitial fibrosis in established renal failure. Kidney Blood Press Res 2004;27:218-225.

-35 Quinkler M, Zehnder D, Eardley KS, Lepenies J, Howie AJ, Hughes SV, Cockwell P, Hewison M, Stewart PM: Increased expression of mineralocorticoid effector mechanisms in kidney biopsies of patients with heavy proteinuria. Circulation 2005;112:1435-1443.

- 36 Shibata S, Nagase M, Yoshida S, Kawachi H, Fujita T: Podocyte as the target for aldosterone: roles of oxidative stress and Sgk1. Hypertension 2007;49:355-364.

- 37 Lea WB, Kwak ES, Luther JM, Fowler SM, Wang Z, Ma J, Fogo AB, Brown NJ: Aldosterone antagonism or synthase inhibition reduces end-organ damage induced by treatment with angiotensin and high salt. Kidney Int 2009;75:936-944.

- 38 Fujisawa G, Okada K, Muto S, Fujita N, Itabashi N, Kusano E, Ishibashi S: Spironolactone prevents early renal injury in streptozotocin-induced diabetic rats. Kidney Int 2004;66:1493-1502.

- 39 Han KH, Kang YS, Han SY, Jee YH, Lee MH, Han JY, Kim HK, Kim YS, Cha DR: Spironolactone ameliorates renal injury and connective tissue growth factor expression in type II diabetic rats. Kidney Int 2006;70:111-120.

-40 Keane WF, Brenner BM, de Zeeuw D, Grunfeld JP, McGill J, Mitch WE, Ribeiro AB, Shahinfar S, Simpson RL, Snapinn SM, Toto R: The risk of developing end-stage renal disease in patients with type 2 diabetes and nephropathy: the RENAAL study. Kidney Int 2003;63:1499-1507. 
-41 Peterson JC, Adler S, Burkart JM, Greene T, Hebert LA, Hunsicker LG, King AJ, Klahr S, Massry SG, Seifter JL: Blood pressure control, proteinuria, and the progression of renal disease. The Modification of Diet in Renal Disease Study. Ann Intern Med 1995;123:754-762.

-42 Widstam-Attorps U, Berg U, Bohman SO, Lefvert AK: Proteinuria and renal function in relation to renal morphology. A clinicopathological study of IgA nephropathy at the time of kidney biopsy. Clin Nephrol 1992;38:245-253.

-43 Ma J, Weisberg A, Griffin JP, Vaughan DE, Fogo AB, Brown NJ: Plasminogen activator inhibitor-1 deficiency protects against aldosterone-induced glomerular injury. Kidney Int 2006;69:1064-1072.

-44 Wilkinson-Berka JL, Tan G, Jaworski K, Miller AG: Identification of a retinal aldosterone system and the protective effects of mineralocorticoid receptor antagonism on retinal vascular pathology. Circ Res 2009;104:124-133.

-45 Ribstein J, Du Cailar G, Fesler P, Mimran A: Relative glomerular hyperfiltration in primary aldosteronism. J Am Soc Nephrol 2005;16:1320-1325.

-46 Greene EL, Kren S, Hostetter TH: Role of aldosterone in the remnant kidney model in the rat. J Clin Invest 1996;98:1063-1068.

-47 Ichikawa I, Ma J, Motojima M, Matsusaka T: Podocyte damage damages podocytes: autonomous vicious cycle that drives local spread of glomerular sclerosis. Curr Opin Nephrol Hypertens 2005; 14: 205-210. 